Gruber. 7. On Volkard's Method of Testing the Chlorides in Urine, by Dr, Max Gruber.

Archives de Physiologie. MM. BRown - St́nUARd, Charcot, Vulpian, and Jofrroy. Vol. III. Series 3. No. 1.-This part contains the subjoined memoirs. 1. On the Influence of Asphyctic Blood on the Nervous Apparatus of the Circulation, by MM. Dastre and Morat. 2. On the Motor Brain, by M. Couty. 3. Pathological Anatomy of Mammary Cystic Disease, by M. Brissaud, with two plates.

The Quarterly Journal of Microscopical Science. Edited by Ray Lankester, Thiselton Dyer, Klein, Moseley, and ADAMr SEDGWICK. No. 93. January, 1884.-This part contains several interesting memoirs; amongst others are the following: Notes on Echinoderm Morphology, by $P$. HerbertCarpenter. On the Homologies of the Primary Larval Plates in the Test of Brachiate Echinoderms, by Mr. Percy Sladen. On the Origin of Metameric Segmentation, and some other Morphological Questions, by Adam Sedgwick, with two plates. On certain Abnormalities in the common Frog, by Alfred Gibbs Bourne, Researches on the Intra-cellular Digestion of Invertebrates, and on the Ancestral History of the Inflammatory Process, by Dr. Elias Metschnikoff. On the Structures connected with the Ovarian Ovum of Marsupialia and Monotremata, by Edwd. Poulton. On the Skeleto. trophic Tissues and Coxal Glands of Limulus Scorpio and Mygale, by E. Ray Lankester. An Improvement in the Method of using the Freezing Microtome, by J. Sollas.

The Birmingham Medical Review. February, 1884.-In this number Dr. Sawyer advocates the employment of some improved oleates, either in the form of a dusting powder or of an ointment. He has found much virtue in the zinc, lead, and copper oleates which have been made by Messrs. Southall, according to the methods devised by Dr. Shoemaker of Phialdelphia.

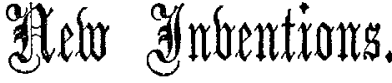

\section{A NEW BINAURAL STETHOSCOPE,}

THIS instrument consists of an ordinary wooden or metal stethoscope, with a tube - which may be either indiarubber or metal-leading from the funnel-shaped portion-i. e., chest.piece. I find it best to use a wooden stethoscope, of which the stem, as well as the bore, is a perfect funnel. In this way, I think, both the wood and the column of air in the stethoscope conduct sound better than in the case of the stethoscopes sold in shops. An indiarubber tube is fitted into the stem, about one inch and a half from the extremity. In using this stethoscope, one ear is applied to the ear-piece in the usual way, and the indiarubber tube is introduced into the other ear. Instead of using indiarubber tubing, one might use metal ; but this makes the instrument too cumbersome and expensive. It may be made in such a way as to fold up alongside of the stem. When indiarubber tubing is used it may be rolled round the stem of the stethoscope. The metal tubing is best used always with a metal stethoscope. Method of using : Introduce the indiarubber tube into one ear firmly. The tube should not be held in the ear with the fingers. The stethoscope is then applied to the patient in the usual way, and the other ear of the operator applied to the ear-piece. If possible the tube should pass behind the neck of the operator. At first sight it would appear that the tube, by rubbing against anything with which it comes in contact, would spoil the examination; but this is not the case, for it can easily be prevented from rubbing against anything; and even if it does it will give rise to no error. The stethoscope can be obtained from Mr. J. Gardner, surgical instrument maker, South Bridge, Edinburgh.

S. WERNICH,

Student of Medicine, Edinburgh University.

\section{THE PAY SYSTEM AT GUY'S HOSPITAL.}

\author{
To the Editor of TrE LANOET.
}

SIR,-The topics discussed by Dr. Steele, under the above heading in your issue of Feb. 2nd, are of so much interest and importance to all who concern themselves with the subject of hospital administration that I trust you will be able to find room for the following remarks upon them.

1. The system of payments initiated at Guy's Hospital is not, as Dr. Steele would have us believe, the provident system of medical relief in any shape or form, but is simply, as stated in your annotation of the previons week, a traos formation of the out-patient department of the hospital into a cheap medicine shop for the sale of advice and medicine at threepence a head. The arguments therefore, based upon the favour which the provident system has met with from the Charity Organisation Society and others, have really no bearing upon the system under discussion. Its closest analogy seems to be to those private ventures with which London is becoming filled, the so-called cheap dispensaries, where advice and medicine can be had for sixpence or a shilling a head, any connexion with which is eschewed by all respectable practitioners. I fail to see why a different rule should apply in the two cases.

2. The comparison between the cost of treating patients in a great endowed hospital like Guy's, and in a parish or union infirmary where it is admitted that they are admirably well cared for, deserves more full consideration than Dr. Steele has devoted to it in his letter. If it be true, as $I$ have been assured on excellent authority, that while the cost per bed in the metropolitan union infirmaries averages $\$ 33$, it rises to nearly $£ 80$ in Guy's and St. Bartholomew's, it is surely not sufficient to account for this enormous difference by reminding us that the latter are handicapped with outpatient departments, high-class nursing, parish and municipal rates, let alone the numerous adjuncts of a medical school. Neither the difference between high-class and lowclass (but efficient) nursing, one would think, nor the rates, were they even heavier than they are, would make very enormous inroads upon an income of $£ 30,000$ a year; while the adjuncts of a medical school, whatever they may be, might, if they be not more than repaid by the gratuitous services of the students to the hospital, be very well left to be supplied by funds derived from sources other than charitable. The out-patient department is, therefore, on Dr. Steele's showing, the most important factor in more than doubling the difficulty of making $£ 30,000$ go as far in an endowed hospital as it does in a parish infirmary.

3. The admission made by Dr. Steele that there is nothing in the testamentary dispositions of the founder nor in the charter of the corporation which refers in any way to outpatients shows, as I have repeatedly urged, that that department is quite foreign to the original design of the great endowed hospitals. Writing ten years ago in Fraser's Magazine (August, 1874), I stated that there could be " no question that the intention of the founders of these institu tions was to make, in the words of Mr. Thomas Guy, a perpetual provision for the maintenance and cure of such poor sick persons as were received into hospital, and that the whole out-patient department, which has had such an enormous development in late years, is something quite foreign to the work originally marked out for hospitals." If the question of legality could be raised therefore, I think it might go much further than either you or Ir. Steele seems to imagine.

4. The indifference of the Charity Commissioners will surprise no one who knows what almost incredible ignorance on hospital matters exists in official circles. So recently as during the last session of Parliament the Minister in charge of the Government Charitable Trusts Bill told a deputation that he had excepted from its action all charities deriving more than half their income trom voluntary subscriptions, and that he thought this would include all hospitals! I am, Sir, yours, \&c.

Dulwich, Feb. 9th, 1884.

H. NELSON HARDY.

VACCINATION GRANTS.-The following gentlemen have received the Government grant for successful vaccination :-Arthur P. May, M.R.C.S., Great Crosby; Mr. F. Felix Jones, Llanfyllin (first time) ; Mr. W. Inglis Mason, Sudbury, Suffolk (fifth time). 